\title{
Interpretasi Struktur Bawah Tanah pada Sistem Sungai Bribin dengan Metode Geomagnet
}

\author{
Khafidh Nur Aziz', Yosaphat Sumardi', Denny Darmawan', dan \\ Nugroho Budi Wibowo ${ }^{2}$ \\ ${ }^{1}$ Jurusan Pendidikan Fisika, Fakultas MIPA, Universitas Negeri Yogyakarta, Yogyakarta \\ ${ }^{2}$ Badan Meteorologi Klimatologi dan Geofisika, Stasiun Geofisika Yogyakarta \\ khafidh.KNA@gmail.com
}

Received 07-01-2016, Revised 28-01-2016, Accepted 07-03-2016, Published 20-04-2016

\section{ABSTRACT}

This research was aimed to determine the distribution pattern of magnetic field anomaly and to identify the lithology of underground structure in Bribin Karst using geomagnetic method. Research location was Semanu Sub-district, Gunungkidul Regency at UTM coordinate of $464061 \mathrm{mT}-464929 \mathrm{mT}$ and $9111097 \mathrm{mU}-9111970 \mathrm{mU}$. The data were taken using G-5 Proton Precession Magnetometer (PPM) by looping method. The result showed that the distribution pattern of the magnetic field anomaly in Karst Bribin has value of $330 \mathrm{nT}-530 \mathrm{nT}$ and anomaly values reflecting the system of Bribin River has value of $400 \mathrm{nT}-460 \mathrm{nT}$. The lithology of underground structure in Karst Bribin has susceptibility value of -0.069 (in SI) 0.0661 (in SI) with depth $200 \mathrm{~m}$ associated with limestone, tuff, gypsum, rock salt, and minerals calcite and anhydrite and the lithology associated with the system of Bribin River has susceptibility value - 0.069 (in SI) associated with gypsum, rock salt, and minerals anhydrite.

Keywords: Geomagnetic, Bribin, Susceptibility, Magnetic Field Anomaly.

\section{ABSTRAK}

Penelitian ini bertujuan untuk mengetahui pola sebaran anomali medan magnet dan mengidentifikasi susunan litologi bawah tanah di wilayah Karst Bribin. Metode yang digunakan adalah metode geomagnet. Lokasi penelitian berada di Kecamatan Semanu, Kabupaten Gunungkidul, DIY pada koordinat UTM 464061 mT - 464929 mT dan 9111097 mU - 9111970 mU. Pengambilan data menggunakan alat Proton Precession Magnetometer (PPM) model Geotron G-5 dengan metode looping. Hasil penelitian menunjukkan bahwa pola sebaran anomali medan magnet di wilayah Karst Bribin memiliki kisaran nilai $330 \mathrm{nT}-530$ nT sedangkan nilai anomali yang mencerminkan sistem Sungai Bribin memiliki kisaran nilai 400 nT - 460 nT. Litologi bawah tanah di wilayah Karst Bribin dengan kedalaman 200 meter memiliki kisaran nilai suseptibilitas -0,069 (dalam SI) - 0,0661 (dalam SI) yang bersesuaian dengan batuan gamping, tufa, gipsum, batu garam, dan mineral kalsit serta anhidrit sedangkan litologi bawah tanah yang berasosiasi dengan sistem Sungai Bribin memiliki nilai suseptibilitas $-0,069$ (dalam SI) dengan kedalaman $\pm 40 \mathrm{~m}- \pm 180 \mathrm{~m}$ yang bersesuaian dengan batu garam, gypsum, dan mineral anhidrit.

Kata kunci: Geomagnet, Bribin, Suseptibilitas, Anomali Medan Magnet.

\section{PENDAHULUAN}

Indonesia merupakan salah satu negara di dunia yang memiliki bentang alam yang beragam, salah satunya adalah karst. Karst adalah daerah yang terdiri atas batuan kapur yang berpori sehingga air di permukaan tanah selalu merembes dan menghilang ke dalam tanah. Istilah karst juga digunakan untuk menggambarkan bentang alam berupa goa dan sistem air bawah tanah oleh batuan yang mudah larut ${ }^{[1]}$. Kabupaten Gunungkidul merupakan salah satu daerah di Indonesia yang memiliki bentang alam berupa karst dan dikenal sebagai kawasan kering, tandus, dan relatif sulit mendapatkan air untuk mencukupi 
kebutuhan sehari-hari terutama pada musim kemarau dikarenakan sedikitnya sungai permukaan dan berkembangnya sungai bawah tanah ${ }^{[2]}$.

Salah satu sungai bawah tanah yang ada di Kabupaten Gunungkidul adalah Sungai Bribin. Sungai Bribin memiliki peranan yang sangat penting bagi penyediaan air karena pada sungai bawah tanah ini. Berdasarkan data lapangan yang diperoleh dari Balai Besar Wilayah Sungai (BBWS) Serayu-Opak, debit air yang terukur di musim kemarau mencapai $2 \mathrm{~m}^{3} /$ det dan debit air yang terukur di musim hujan mencapai $4 \mathrm{~m}^{3} /$ det. Oleh karena pentingnya keberadaan sungai bawah tanah dan potensi sumber daya air yang tinggi, maka perlu dikembangkan metode untuk menginterpretasikan struktur bawah tanah pada sistem sungai bawah tanah.

Metode geomagnet merupakan salah satu metode geofisika yang sering digunakan untuk survei pendahuluan pada eksplorasi minyak bumi, gas bumi, arkeologi, sesar, logam, zona akumulasi air bawah tanah dan mineral ${ }^{[3]}$. Metode geomagnet digunakan untuk menginterpretasikan struktur bawah tanah berdasarkan sifat-sifat magnet batuan yang terdapat di bawah $\operatorname{tanah}^{[4]}$. Oleh karena itu, metode ini diharapkan mampu untuk menginterpretasikan struktur bawah tanah pada daerah yang memiliki sistem sungai bawah tanah.

\section{METODE}

Pengambilan data dilaksanakan pada tanggal 9-11 Februari 2015 di Desa Dadapayu, Kecamatan Semanu, Kabupaten Gunungkidul, DIY dengan koordinat UTM 464062 mT $464929 \mathrm{mT}$ dan $9111097 \mathrm{mU}$ - 9111970 mU. Gambar 1 menunjukkan lokasi daerah penelitian.

Instrumen yang digunakan dalam penelitian ini adalah perangkat keras dan perangkat lunak. Perangkat keras yang digunakan adalah satu set Proton Precession Magnetometer (PPM) model Geotron G-5, Global Positioning System (GPS), dan buku kerja. Perangkat lunak yang digunakan adalah software Microsoft Office 2013, Surfer 12, Global Mapper 13, Google Earth, Mag2DC, OASIS Montaj 6.4.2, dan Corel Draw X7.

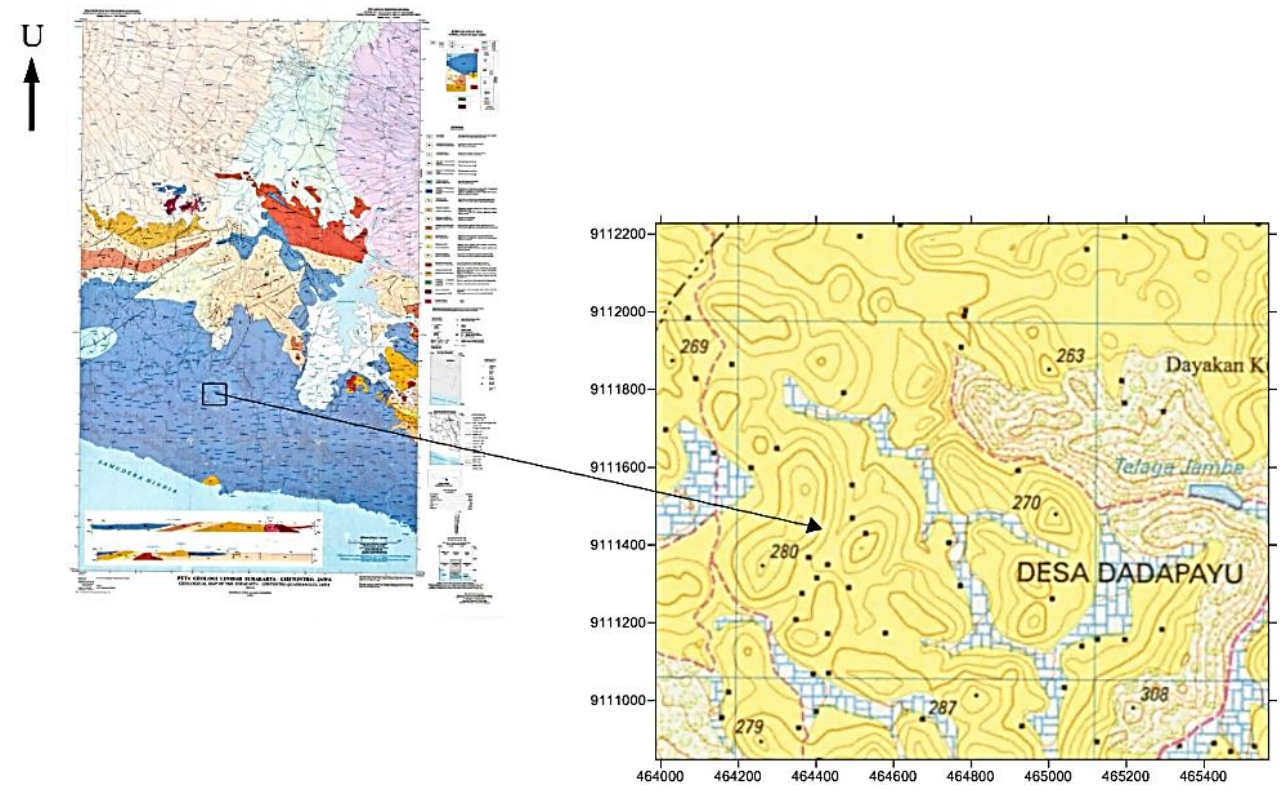

Gambar 1. (color online) Letak Daerah Penelitian dalam Peta Geologi Lembar Surakarta-Giritronto, Jawa ${ }^{[5]}$ dan Peta RBI Lembar Semanu ${ }^{[6]}$ 
Pada tahap akuisisi data digunakan metode looping, yaitu penggunaan satu set PPM dengan pengukuran diawali dan diakhiri di base. Dengan kata lain, satu set PPM berfungsi sebagai base dan rover.

Pada tahap pengolahan data, untuk mendapatkan nilai anomali medan magnet, terdapat dua proses koreksi yang diterapkan, yaitu koreksi variasi harian $(\Delta F)$ dan koreksi IGRF $(F)$. Nilai variasi harian didapatkan dengan persamaan ${ }^{[7]}$ :

$$
\Delta F=\frac{t_{n}-t_{a}}{t_{b}-t_{a}}\left(T_{b}-T_{a}\right)
$$

dengan $t_{n}$ adalah waktu saat pengukuran dalam detik, $t_{a}$ adalah waktu terukur di base awal dalam detik, $t_{b}$ adalah waktu terukur di base akhir dalam detik, $T_{b}$ adalah nilai medan magnet total pada base akhir dalam nT, dan $T_{a}$ adalah nilai medan magnet total pada base awal dalam nT. Setelah dilakukan koreksi variasi harian selanjutnya dilakukan koreksi IGRF. Koreksi IGRF didapatkan dari website National Oceanic and Atmospheric Administration (NOAA). Setelah mendapatkan nilai variasi harian dan nilai IGRF, untuk mendapatkan nilai anomali medan magnet $(\Delta T)$ digunakan persamaan ${ }^{[8]}$ :

$$
\Delta T=T-\Delta F-F
$$

dengan $T$ adalah nilai medan magnet dalam nT, $\Delta F$ adalah nilai variasi harian dalam $\mathrm{nT}, F$ adalah nilai IGRF dalam nT.

Setelah didapatkan nilai anomali medan magnet, kemudian dilakukan proses reduksi ke kutub untuk menghilangkan pengaruh sudut inklinasi dan sudut deklinasi. Setelah dilakukan reduksi ke kutub, dilakukan kontinuasi ke atas untuk menghilangkan pengaruh lokal yang berasal dari sumber-sumber di permukaan. Gambar 2 menunjukkan diagram alir dari penelitian ini.

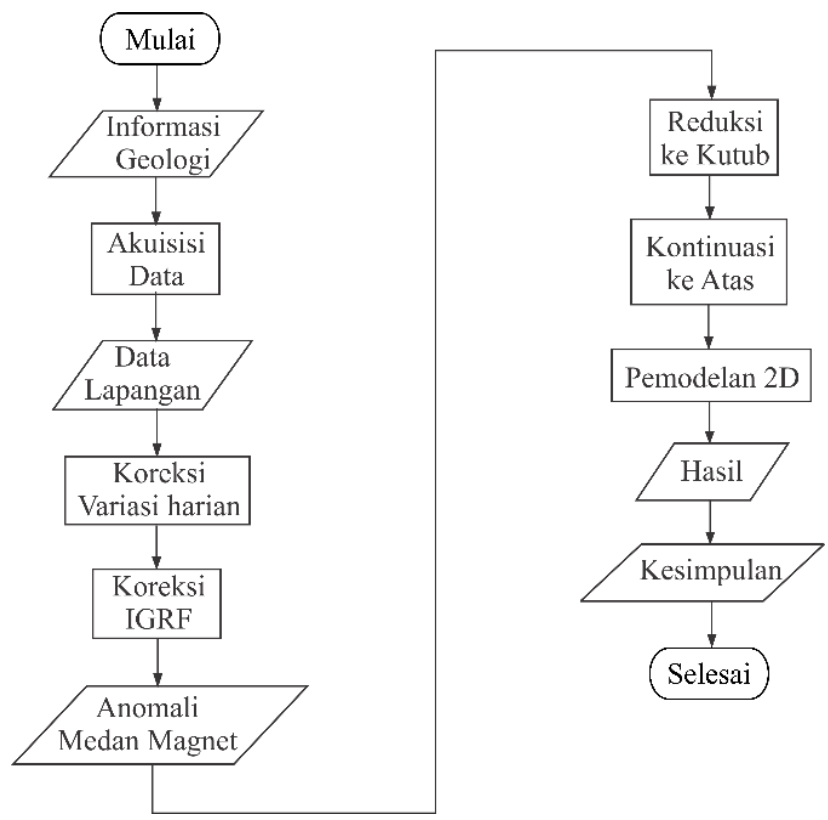

Gambar 2. Diagram Alir Penelitian 


\section{HASIL DAN PEMBAHASAN}

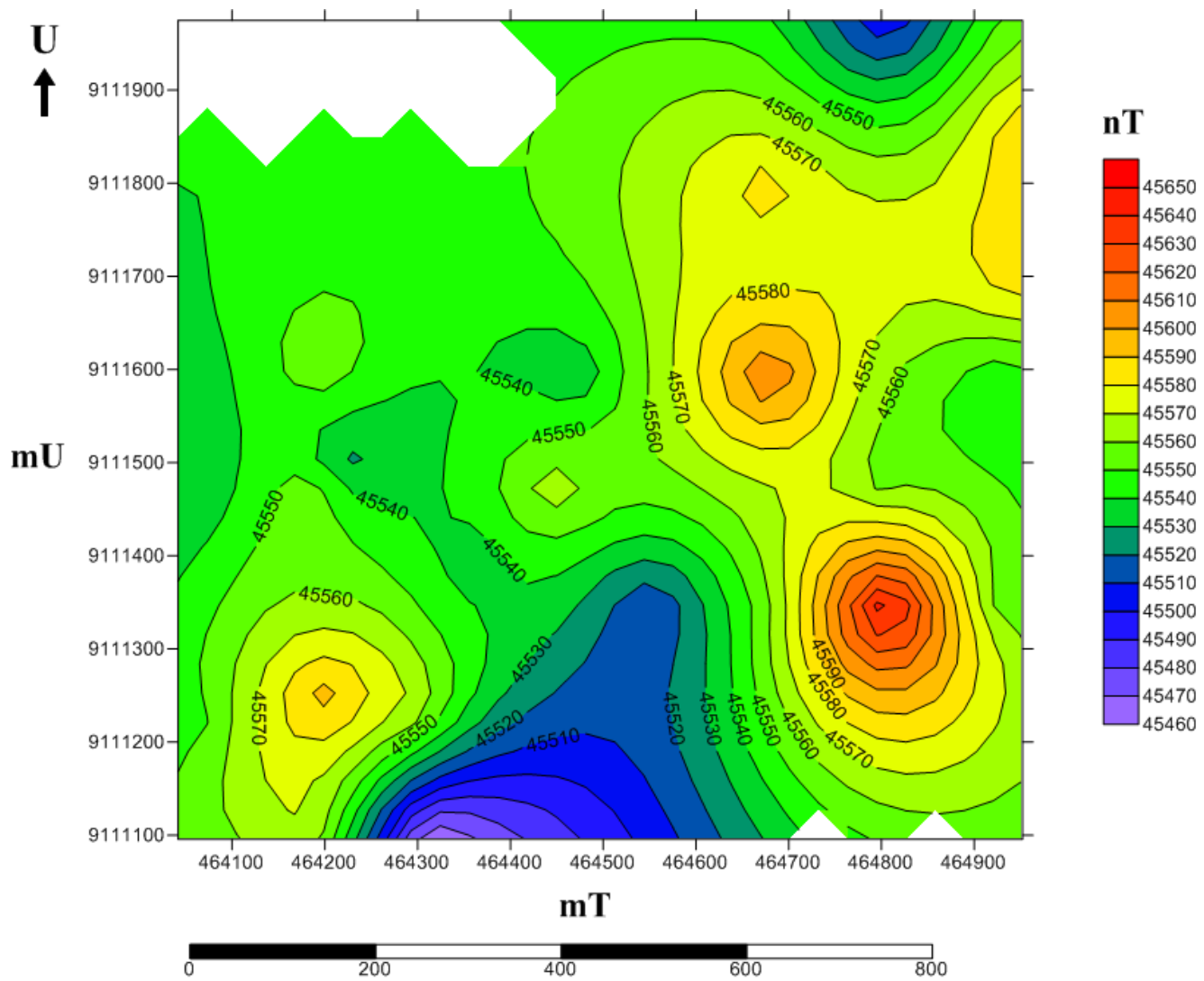

Gambar 3. (color online) Kontur Medan Magnet Total

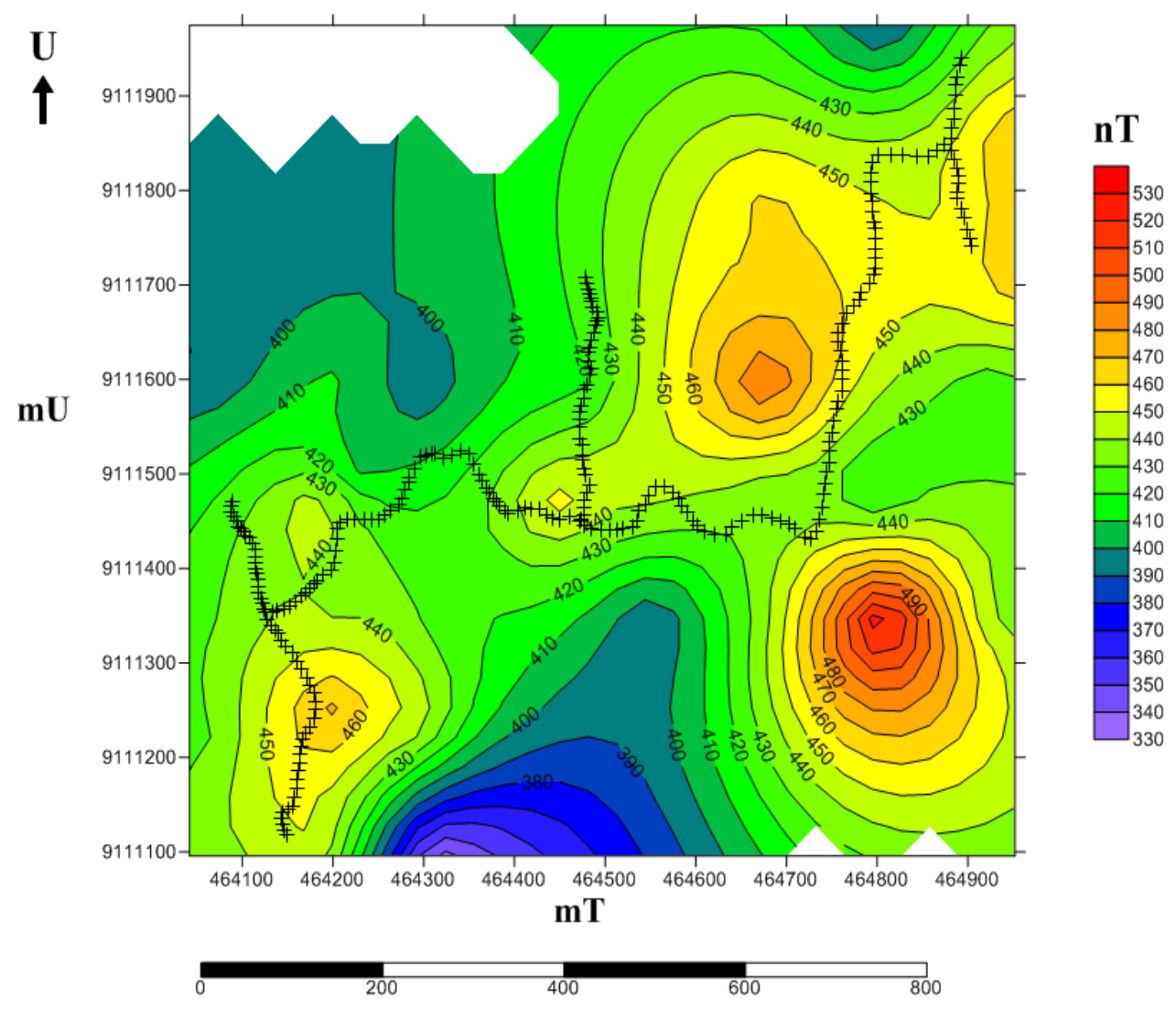

Gambar 4. (color online) Kontur Anomali Medan Magnet dan Overlay Jalur Sungai Bribin (Ditandai dengan Simbol +) 
Pengambilan data di lapangan dengan alat ukur geomagnet menghasilkan data medan magnet total. Gambar 3 menunjukkan kontur medan magnet total di wilayah Karst Bribin yang memiliki kisaran nilai medan magnet total antara 45,460 nT-45,650 nT. Kontur medan magnet total didominasi dengan nilai 45,540 nT. Gambar 2 belum merepresentasikan sistem sungai bawah tanah di wilayah karst Bribin karena masih dipengaruhi oleh medan magnet regional dan medan magnet luar.

Anomali medan magnet dihasilkan dengan melakukan beberapa koreksi, yaitu koreksi variasi harian dan koreksi IGRF. Setelah dilakukan pengolahan data untuk mendapatkan nilai anomali medan magnet, dihasilkan kontur anomali medan magnet yang disajikan pada Gambar 3.

Gambar 3 menunjukkan pola sebaran anomali medan magnet wilayah Karst Bribin yang memiliki kisaran nilai anomali medan magnet antara 330 nT-530 nT. Wilayah Karst Bribin memiliki kisaran nilai anomali medan magnet yang tidak terlalu lebar. Hal ini terjadi karena batuan penyusun daerah penelitian masuk dalam formasi Wonosari yang didominasi oleh batu gamping. Gambar 4 menunjukkan bahwa pola sebaran anomali medan magnet yang merepresentasikan sistem sungai bawah tanah di wilayah Karst Bribin memiliki nilai berkisar antara $400 \mathrm{nT}-460 \mathrm{nT}$.

Reduksi ke kutub dilakukan dengan cara membawa medan magnet bumi sedemikian sehingga kondisi medan magnet pada daerah penelitian menjadi seperti kondisi di kutub utara medan magnet untuk menunjukkan langsung posisi bendanya. Proses ini mengubah parameter medan magnet bumi pada daerah penelitian yang memiliki rata-rata nilai deklinasi $1^{\circ}$ dan inklinasi $-33^{\circ}$ menjadi kondisi di kutub yang memiliki deklinasi $0^{\circ}$ dan inklinasi $90^{\circ}$. Hasil dari proses reduksi ke kutub disajikan pada Gambar 5.

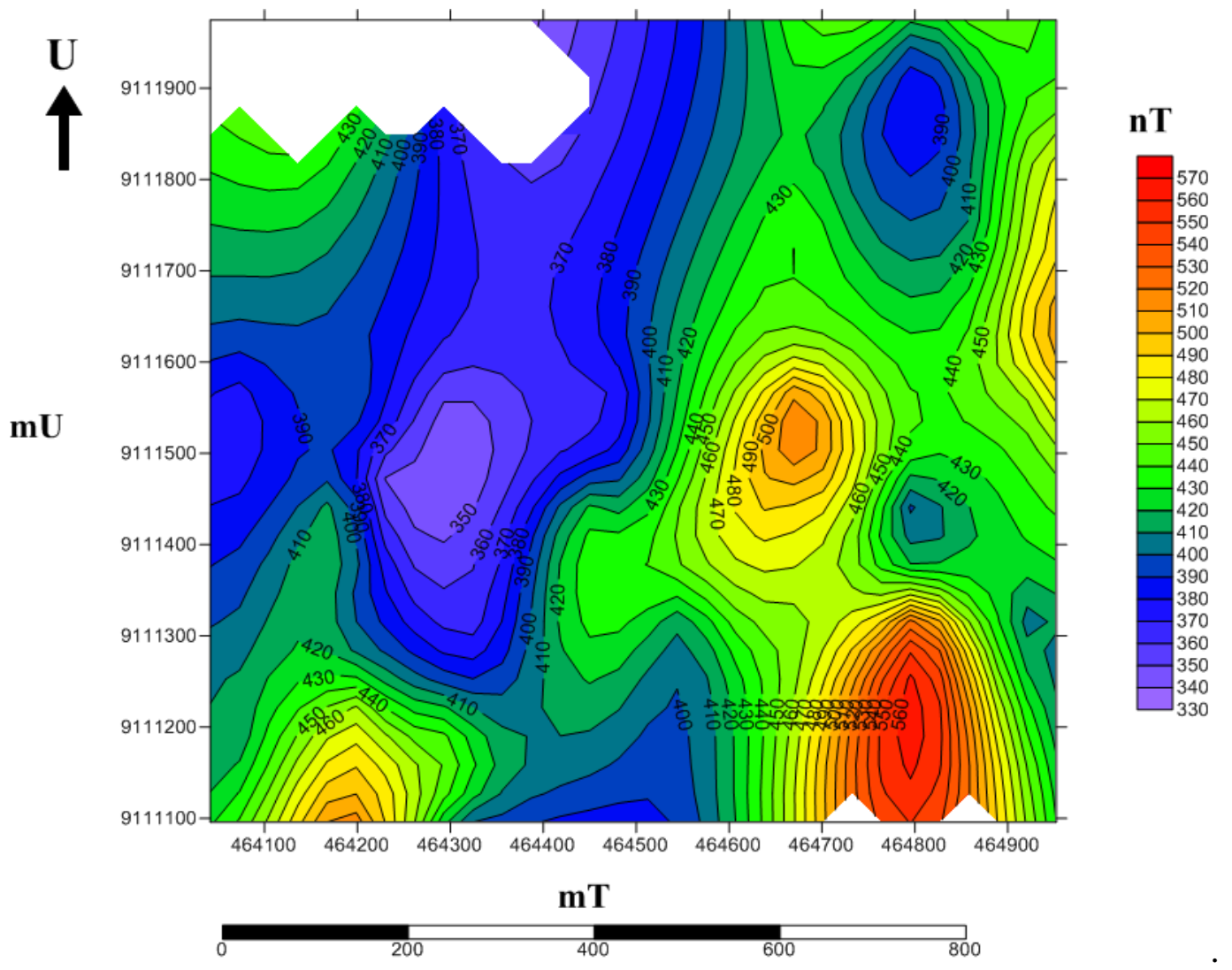

Gambar 5. (color online) Kontur Reduksi ke Kutub 
Kontur anomali reduksi ke kutub masih merupakan campuran antara anomali regional dan anomali lokal. Oleh karena itu, kontinuasi ke atas diperlukan dengan tujuan untuk proses low pass filtering, yaitu untuk memfilter anomali lokal. Penentuan ketinggian kontinuasi dilakukan dengan cara trial and errors dan melihat kecenderungan pola kontur hasil kontinuasi. Gambar 6 menunjukkan kontur anomali medan magnet hasil kontinuasi ke atas pada ketinggian $30 \mathrm{~m}, 100 \mathrm{~m}$, dan $170 \mathrm{~m}$ dari permukaan.

Pemilihan kontur kontinuasi ke atas pada ketinggian $170 \mathrm{~m}$ didasarkan pada kecenderungan perubahan kontur pada ketinggian tersebut yang tidak mengalami perubahan signifikan ketika dilakukan kontinuasi ke atas dari ketinggian sebelumnya dan kecenderungan dari klosur yang tidak rapat, serta tidak jauh dari klosur kontur sebelumnya.

170 meter

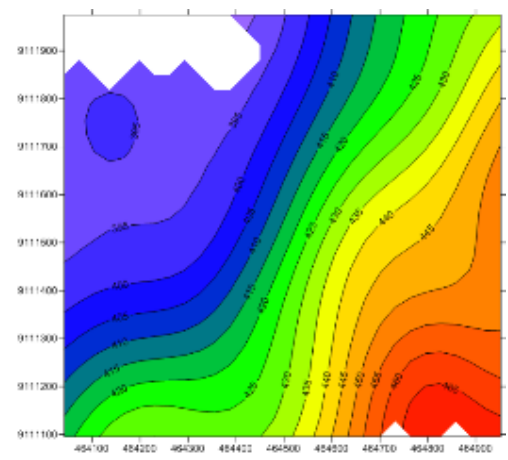

100 meter

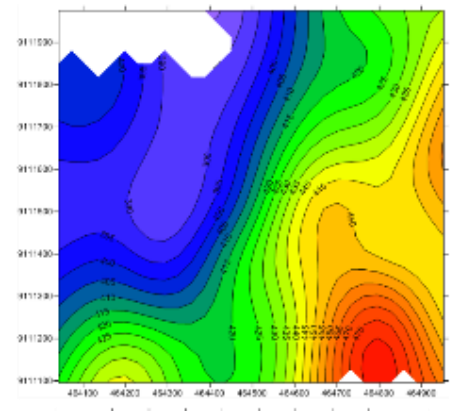

30 meter

RTP

Kontur Anomali

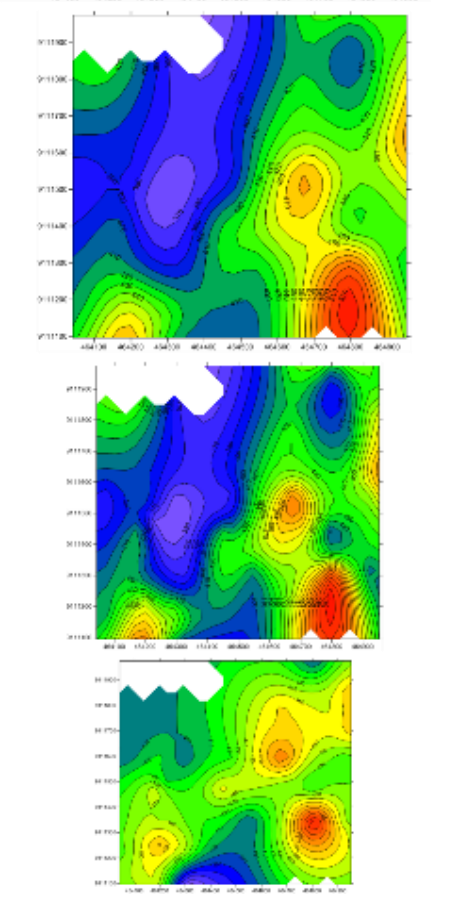

Gambar 6. (color online) Kontur Kontinuasi ke Atas 
Pemodelan 2D dilakukan dengan membuat model struktur bawah tanah menggunakan software Mag2DC dengan cara membuat sayatan yang melewati bidang anomali. Pemilihan posisi sayatan berdasarkan hasil dari kontinuasi ke atas yaitu pada ketinggian 170 m. Dalam pemodelan ini, posisi sayatan ditunjukkan pada Gambar 7.

Gambar 7 menunjukkan bahwa nilai anomali medan magnet setelah dilakukan kontinuasi ke atas berkisar antara $385 \mathrm{nT}-470 \mathrm{nT}$. Hasil pemodelan 2D disajikan pada Gambar 8 beserta dengan keterangannya yang disajikan pada Tabel 1.

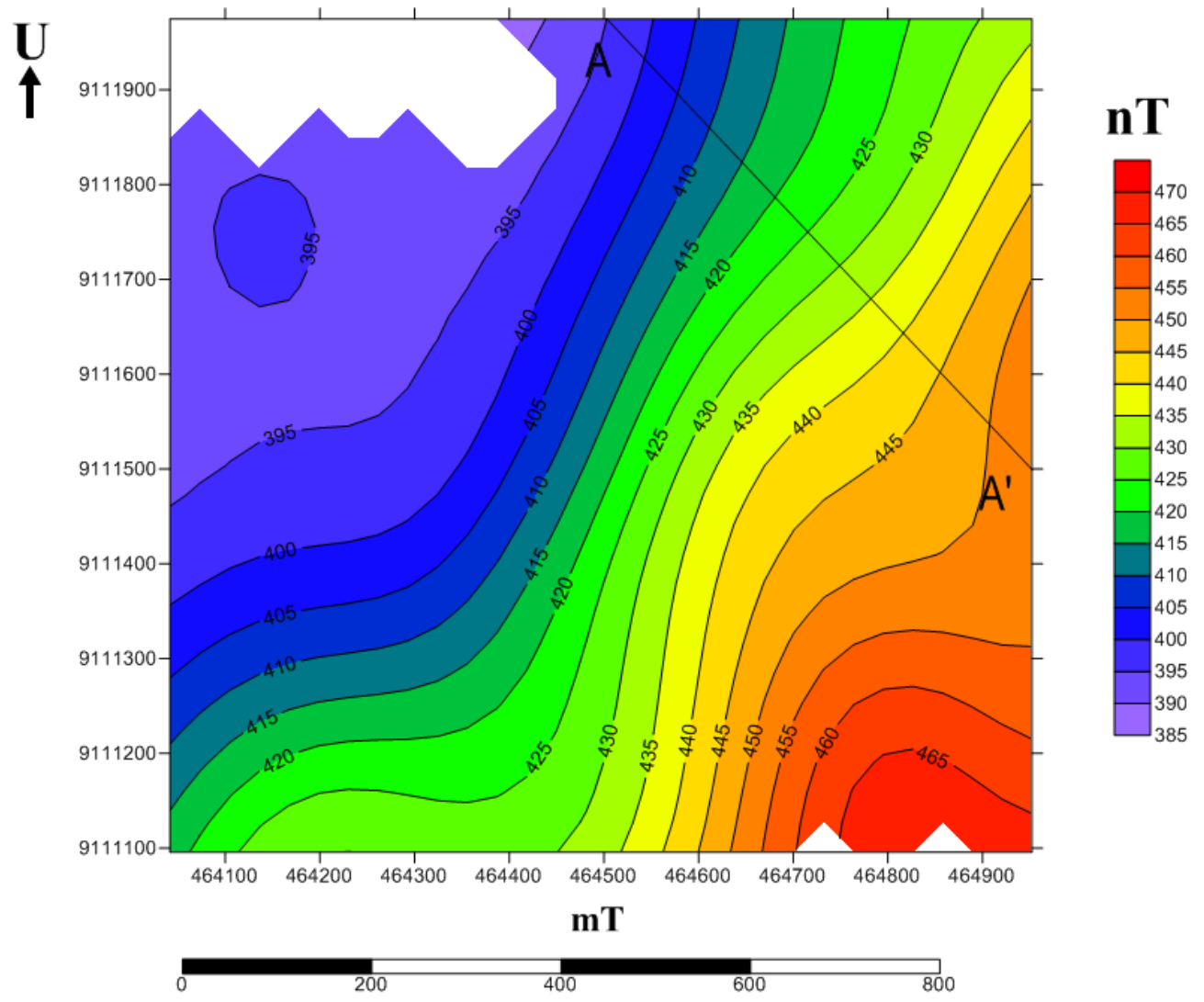

Gambar 7. (color online) Kontur Kontinuasi Ketinggian 170 m

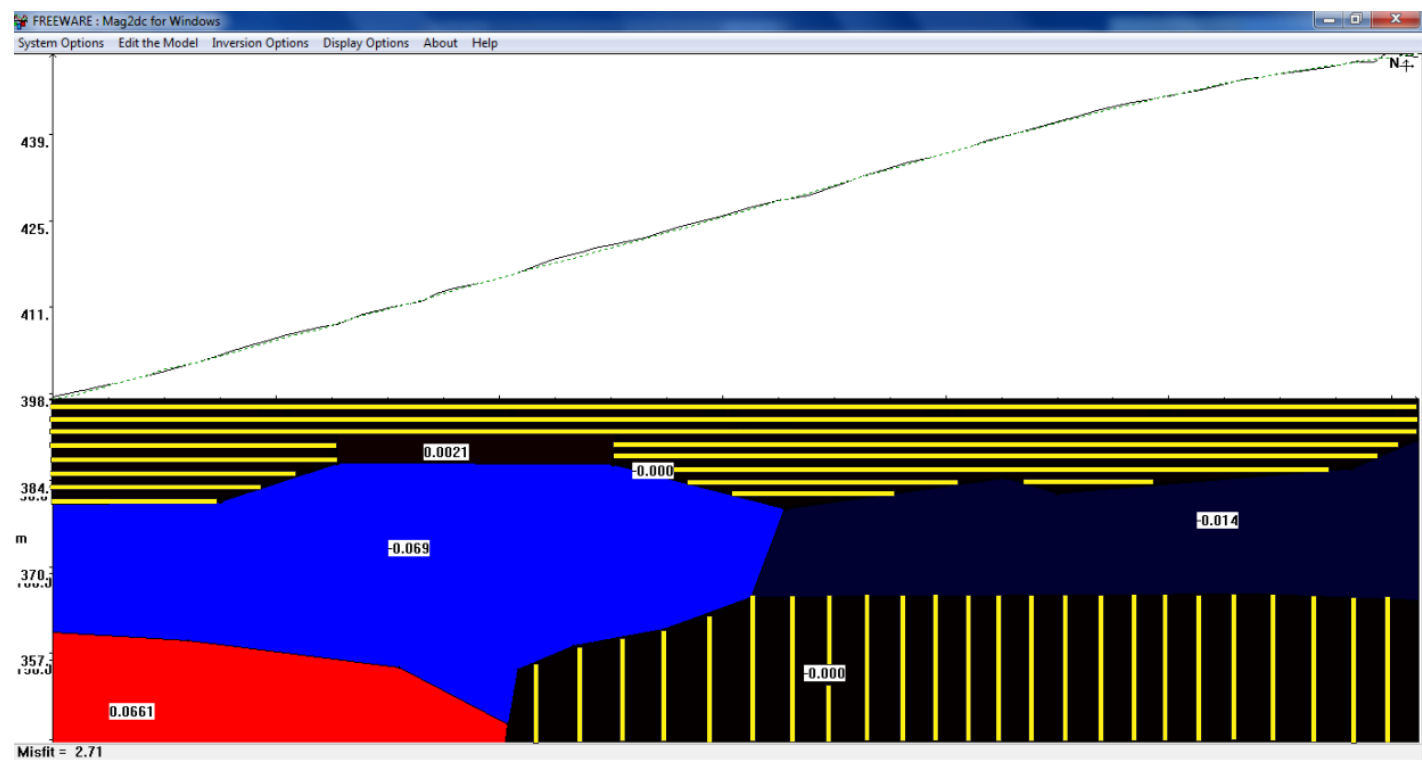

Gambar 8. (color online) Hasil Pemodelan 2D 
Tabel 1. (color online) Nilai Suseptibilitas Hasil Pemodelan

\begin{tabular}{|c|c|c|c|c|}
\hline No & Model & $\begin{array}{c}\text { Suseptibilitas } \\
\text { (SI) }\end{array}$ & $\begin{array}{l}\text { Kedalaman } \\
\text { (m) }\end{array}$ & Jenis Batuan dan Mineral \\
\hline 1 & & 0,0661 & $\pm 125-200$ & $\operatorname{Tufa}^{[9,10]}$ \\
\hline 2 & & 0,0021 & $\pm 25- \pm 35$ & Batu Gamping ${ }^{[11]}$ \\
\hline 3 & & $-0,000001$ & $0- \pm 60$ & Kalsit $^{[11]}$ \\
\hline 4 & & $-0,0005$ & $\pm 110-200$ & $\begin{array}{l}\text { Anhidrit, gipsum, dan atau batu } \\
\text { garam }^{[11]}\end{array}$ \\
\hline 5 & & $-0,014$ & $\pm 30- \pm 110$ & $\begin{array}{l}\text { Anhidrit, gipsum, dan atau batu } \\
\text { garam }^{[11]}\end{array}$ \\
\hline 6 & & $-0,069$ & $\pm 40- \pm 180$ & $\begin{array}{l}\text { Anhidrit, gipsum, dan atau batu } \\
\text { garam }^{[11]}\end{array}$ \\
\hline
\end{tabular}

Interpretasi dilakukan setelah proses pembuatan model secara 2D dan selanjutnya dilakukan penggabungan model 2D untuk mempermudah interpretasi. Berdasarkan hasil pemodelan 2D yang disajikan Gambar 8 beserta keterangan pada Tabel 1 diketahui bahwa struktur geologi daerah karst yang memiliki sistem sungai bawah tanah memiliki bentuk yang berbeda untuk tiap formasi batuan penyusun. Wilayah Karst Bribin termasuk dalam formasi Wonosari dan termasuk ke dalam subsistem Wonosari-Baron yang tersusun atas batu gamping, terumbu, batu vulkanik tufa, breksi, dan lava ${ }^{[9]}$. Berdasarkan data lapangan yang diperoleh, daerah penelitian memiliki elevasi antara $217 \mathrm{~m}-293 \mathrm{~m}$ dan diketahui bahwa letak sistem sungai bawah tanah di daerah yang dimodelkan memiliki kedalaman $\pm 74 \mathrm{~m}^{[12]}$.

Hasil pemodelan 2D menunjukkan bahwa daerah sayatan AA' memiliki kisaran nilai suseptibilitas -0,069 (dalam SI)-0,0661 (dalam SI) yang bersesuaian dengan batuan batu gamping dan tufa dan mineral kalsit dan anhidrit, gipsum, dan atau batu garam sedangkan litologi bawah tanah yang berasosiasi dengan sistem sungai bawah memiliki nilai suseptibilitas -0,069 (dalam SI) yang bersesuaian denga mineral anhidrit, gipsum, dan atau batu garam dengan kedalaman $\pm 40 \mathrm{~m}- \pm 180 \mathrm{~m}$. Berdasarkan nilai suseptibilitas, jenis material batuan dan mineral di daerah penelitian termasuk material diamagnet dengan nilai suseptibilitas $k<0$ dan material paramagnet dengan nilai suseptibilitas $10^{-6}<k<1$.

\section{KESIMPULAN}

Berdasarkan penelitian yang telah dilakukan dengan metode geomagnet, dapat disimpulkan bahwa pola sebaran anomali medan magnet di wilayah Karst Bribin memiliki kisaran nilai 330 nT-530 nT sedangkan nilai anomali yang mencerminkan sistem sungai bawah tanah memiliki kisaran nilai 400 n-460 nT. Litologi bawah tanah di wilayah Karst Bribin memiliki kisaran nilai suseptibilitas -0,069 (dalam SI)-0,0661 (dalam SI) dengan kedalaman $200 \mathrm{~m}$ yang bersesuaian dengan batuan batuan gamping, tufa, gipsum, batu garam, dan mineral kalsit serta anhidrit sedangkan litologi bawah tanah yang berasosiasi dengan sistem sungai bawah memiliki nilai suseptibilitas -0,069 (dalam SI) dengan kedalaman $\pm 40 \mathrm{~m}- \pm 180 \mathrm{~m}$ yang bersesuaian gipsum, batu garam, mineral anhidrit. . 


\section{UCAPAN TERIMAKASIH}

Terimakasih kepada Pemerintah Kabupaten Gunungkidul, Dinas Pekerjaan Umum, dan masyarakat desa Dadapayu yang telah banyak membantu baik berupa izin penelitian, fasilitas tempat, sarana, dan kemudahan dalam kegiatan penelitian ini. Tidak lupa kami ucapkan banyak terima kasih kepada Prodi Geofisika Universitas Gadjah Mada yang telah memberikan izin menggunakan alat PPM dan operator untuk membantu mengoperasikan alat PPM. Begitu juga dengan rekan-rekan geofisika Universitas Negeri Yogyakarta dan Universitas Islam Negeri Sunan Kalijaga yang telah bersama-sama di lapangan untuk membantu pengambilan data dan diskusi yang bermanfaat.

\section{DAFTAR PUSTAKA}

1 Ford, D. and Williams, P. 2007. Karst Hydrogeology and Geomorphology. Chicester: John Wiley \& Sons ltd.

2 Astuti, R. K. 2014. Pemodelan 2D Sungai Bawah Tanah Seropan Dengan Metode VLF - EM di Kecamatan Semanu Kabupaten Gunungkidul. Abstrak Tesis Ilmu Fisika UGM. Diakses dari http://etd.repository.ugm.ac.id/index.php?mod=opac\&sub=Opac\&act=view \&typ=html \&self=1\&op=opac pada tanggal 3 September 2015.

3 Roux, A. T. 1980. Geophysical Field Manual for Technicians (No. 1 the Magnetic Method). Afrika Selatan: South African Geophysical Association.

4 Suwardi, B. N., Wahyudi, dan Suyanto, I. 2004. Analisis Data Magnetik untuk Mengetahui Struktur Bawah Permukaan Daerah Manifestasi Airpanas di Lereng Utara Gunungapi Ungaran. Prosiding, Pertemuan Ilmiah Tahuan ke-29 Himpunan Ahli Geofisika Indonesia, Yogyakarta 5-7 Oktober 2004. Diakses dari http://geothermal.ft.ugm.ac.id/gothermal-geophysics/ pada tangal 1 Oktober 2015.

5 Surono, Toha, B., dan Sudarno, I. 1992. Peta Geologi Lembar Surakarta-Giritronto, Jawa. Bandung: Pusat Penelitian dan Pengembangan Geologi.

6 BAKOSURTANAL. 1999. Peta Rupa Bumi Digital Indonesia Skala 1:25.000 Lembar 1407-634 Semanu Edisi: 1-1999. Bogor: Badan Koordinasi Survey dan Pemetaan Nasional.

7 Gravmag. 2015. Magnetic Data Acquisition. Diakses dari http://gravmag.ou.edu/mag_measure/magnetic_measure.html pada tanggal 3 September 2015.

8 Blakely, R. J. 1996. Potential Theory in Gravity and Magnetic Applications. Edinburgh: Cambridge University Press.

9 Kusumayudha, S. B. 2005. Hidrogeologi Karst dan Geometri Fraktal di Daerah Gunungsewu. Yogyakarta: Adi Cita.

10 Nuha, D.Y.U., dan Avisena, N. 2012. Pemodelan Struktur Bawah Permukaan Daerah Sumber Air Panas Songgoriti Kota Batu Berdasarkan Data Geomagnetik. Jurnal Neutrino, Vol. 4, No. 2, Hal. 178-187.

11 Telford, W. M., Geldart, L. P., and Sheriff, R. F. 1990. Applied Geophysics Second Edition. Edinburgh: Cambridge University Press. 